\title{
Assessing the EU's commitment to multilateralism CSDP and Member States' propensity to participate in peace missions
}

\author{
FULVIO ATTINÀ \\ University of Catania \\ attinaf@unict.it
}

\begin{abstract}
This paper analyzes the contribution of the CSDP operations to the peace building tasks of the peace operations of the global system, and examines the different levels of participation of EU Member States. Section one presents the scenario and considers the growth and expansion of practice of peace operations in the last twenty years. Section two reviews the main attributes of the CSDP operations. Section three explores the contribution of the old and new Member States to CSDP by examining the number of operations these countries participated in. The concluding section summarizes the research findings, and points to the current challenges faced by the EU's peace missions.
\end{abstract}

Keywords: CSDP, European Union, Multilateral security, Peace building, Peace operations, Post-conflict reconstruction

\section{Introduction}

In 1999, at Helsinki, the European Council decided to start building the EU's military and civilian capabilities in peace operations and post-conflict reconstruction. Four years later, the European Union was ready to launch the first ESDP (European Security and Defence Policy) operation. In the following years, the peace operations of the European Union have to some extent contributed the growth of multilateral security and the change of peace operations in the world system. This contribution has been qualitative rather than quantitative. It has influenced the change of peace operation tasks by sustaining the growth of non-military operations, rather than encouraging military intervention. This paper deals with the issues and trends in peace operations and highlights the main features of the EU's contribution to these trends. It also analyzes the different roles and levels of involvement of the EU Member States in the operations. This reveals that certain Member States enjoy an elevated status in these operations. In 2004 and 2007 the EU membership was extended to seven Central and East European countries, three Baltic states, and two Mediterranean island-states. Consequently, the EU's peace operations have been strengthened by the additional military and civilian 
resources of these countries, and these countries have been familiarized to the EU-styled missions.

Section one of this paper examines the overall growth and task expansion of the peace operation practice, and highlights the rise of the post-conflict reconstruction goal. Section two reviews the chief characteristicsand the main trends of the CSDP operations and demonstrates the EU's pivotal role in advancing that goal. Section three assesses the presence of the Member States in the EU's operations, and investigates how mission costs and lead positions are assigned to the EU Member States. The concluding section briefly canvasses the main characteristics of the CSDP operations, that have been analysed in this paper, and points to the principal challenges faced by the EU's peace missions both now and in the future.

This paper has used data from the CSDP operations 2010 dataset of the ADISM Project ${ }^{1}$ This database contains information on the 26 multilateral missions the European Union organized from 2003-2010. The project defines a peace operation as the action of a group of states, normally legitimated by an international organisation, that employs military, police and civil personnel from the participating states with a mandate for tasks such as peacekeeping, peace building, state re-construction, and peace enforcement.

\section{CSDP and the changes in peace operations in recent years}

The authorities of the European Union firmly and repeatedly claim that multilateralism is the foundation of all European international actions. In the security field, this claim is manifest in the military and civilian capabilities of crisis management, conflict resolution and state post-conflict reconstruction that the EU's authorities have created within the frame of the Common security and defence policy or CSDP as the Lisbon Treaty renamed the earlier existent European security and defence policy (ESDP).

The large body of literature on the EU operations continues to grow. The 1999 Helsinki European Council's Headline Goals that aimed at building the European capabilities of crisis management and the subsequent introduction of military and civilian operations have inspired much research. CSDP operation analysts have focused either on the organisation of this instrument of the EU foreign policy or on the detailed analysis of selected mission cases. Their main concern is to learn lessons from past and present cases in order to advise the policy-makers about common actions and policies in the future security arena. The inclination of the CSDP specialists to concentrate on the building of CSDP operations and to deal with this experience as a sui generis phenomenon is based on the special nature and goal of the CSDP military and civilian

\footnotetext{
${ }^{1}$ See $<$ http://www.fscpo.unict.it/adism/adism.htm $>$, accessed 20 January, 2011. ADISM is the Italian acronym for the Data Archive on Italy and Multilateral Security, the research project of the Department of Political Studies of the University of Catania that seeks to collect, disseminate, and use quantitative data for the study of international security, multilateralism, and the foreign policy of Italy. The chief ADISM dataset contains the data of 205 multilateral peace operations organised by the United Nations, international organisations and ad-hoc coalitions in the time period October 1st, 1947 to September 1st, 2008.
} 
capabilities. These are the instruments a group of countries makes use of to solve distinct cases of conflict in close and distant geographical areas. These are also the building blocks of the EU's defence policy. The study of the internal aspects of the preparation and organisation of the European peace missions is of both scientific and practical concern. To facilitate the intervention of the European countries and the deployment of the EU common force in distinct crises it is of utmost importance to know all the aspects of EU negotiation and decision-making process. This often entails a delicate blend of military and civilian resources of the Member States and balancing these countries' different national practices, cultures, interests, and aspirations.

CSDP operations also appraise and assess the large body of knowledge that analysts produce about the change of the multilateral operation mechanism as it is run by the security organisations that currently practice multilateral security. Nowadays, peace building missions, mandated to halt international and domestic conflict and accomplish assignments, such as protecting minorities, transferring refugees, and reconstructing the political, civil and administrative structures of the target state, have superseded in number and importance the peacekeeping missions that are mandated only to watch over truces and cease-fires. The most common case today is the deployment of integrated peace missions, i.e. multi-task missions aimed at simultaneously carrying out military, political, civil, administrative, and police tasks. This transformation of peace operation tasks goes along with the changes in demand and supply factors. The growing number of violent conflicts in the 1980 s and 1990s, and the devolution of violence control to the United Nations and regional security organizations after the end of the Cold War have been declining in the last ten years. Social conflict has worsened in a growing number of countries which have been plagued by economic backwardness and political repression, and has become the most important demand factor. On the supply side, the propensity for well-off, western countries, and for the United Nations and inter-governmental organisations of Europe and Africa to take on themselves the organisation and costs of "defending and re-building" has been reinforced by the adhesion of these actors to the new principle of the responsibility to protect. In addition to this, Non-Western countries, especially the large states of Asia, have entered into the peace operation supply business and contributed military personnel to the United Nations peace missions on a large scale. This fact notwithstanding, the change of supply and demand factors and, especially, the transformation of the tasks of the peace operations underpin the belief that peace building operations are the tool of the dominant (Western) coalition's strategy of transmitting norms and practices from the centre to the peripheries of the world system. A number of analysts contend that multilateral security missions are both conflict management tools and the principal instrument used by coalition countries to diffuse the 'Western model' to the rest of the world ${ }^{2}$.

It is worth remembering that the assessment of the reasons for both the growth in number and the change of tasks in multilateral security operations does not address the issue of the efficacy of multilateral intervention. The peace mission mechanism normally

${ }^{2}$ See K. Légaré, 'The 'schizophrenic' nature of peacebuilding operations: between external supervision and self-rule,' in F. Attinà and D. Irrera (eds.), Multilateral security and ESDP operations, Farnham, Ashgate, 2010, pp. 35-50. 
confronts the symptoms, i.e. the eruption and use of violence, and not the deep causes of the conflicts, such as hostility between states and repression in domestic politics that multilateral intervention aims to solve. Action on the symptoms frequently brings unwanted, negative results like the breakdown of the social structure of the target state, and the introduction of new forms of crime. Lastly, the process of change which the actors of multilateral intervention intend to precipitate is laden with inherent limitations because the missions are usually under-resourced and too short in duration to provide and maintain the necessary conditions for order and stability to the receiving states. Multilateral intervention usually achieves the goal of immediate interruption of violence, but seldom has the long-term of political, ideally democratic, stabilization of the target country. This kind of intervention rarely provides the very long effort and large resource allocation necessary to effect meaningful change on the political, economic and cultural structures of the target country.

Change in the peace operation agency is also one of the much debated issues by the students of multilateral security. ${ }^{.}=$It raises many questions. Are the missions organized at the region level suited to accomplish the peace building task better than the UN-led ones? Have Non-UN operations a detrimental effect on the UN security role? Is the growth of minilateralism as a form of crisis management, around the corner? NonUN-led operations have been always organised by international organizations and state coalitions but since the early 1990 s their incidence has been increasing considerably. This change, however, is far from being a neat one. The UN-led operations coexist with the UN-authorized and UN-endorsed regional organisation ones as well as with minilateral operations, i.e. the operations of international organizations and coalitions of states which have no UN authorization and endorsement. This change is the consequence of the erosion of the United States and Western countries' global leadership. 4 The build-up of the CSDP operations can be explained as a political choice by the EU's policymakers. By acting autonomously in multilateral security and playing out primarily the role of the civilian (rather than military) actor of conflict resolution and peace building, EU policymakers are containing the decline.

The basic precondition for establishing peace operations remains the propensity of the states to bear the considerable costs of intervention in international and civil wars. Empirical analysis of countries like France, Italy, Spain, and Sweden demonstrates that these European countries belong to a group of states that have the attributes such as

\footnotetext{
3 See A. J. Bellamy and P. Williams, 'Who's keeping the peace? Regionalization and contemporary peace operations,' International Security, Vol. 29, No. 4, 2005, pp. 157-195. D. McDougall, 'The regionalization of peacekeeping and peacebuilding: lessons learnt in East Timor and the Southwest Pacific,' in Attinà and Irrera, op. cit., pp. 51-70. S. Riesche, 'Bosnia, Darfur, and the 'Actorness' of Regional Organisations. Assessing the Performance of Regional(ised) Peace and Security Operations', ibidem, pp.125-144. P. S. Sidhu Waheguru, 'Regionalisation of Peace Operations,' in Espen Barth Eide (ed.), Effective Multilateralism: Europe, Regional Security and a Revitalized UN, Foreign Policy Centre, British Council, 2006, pp. 32-37. P. Wallensteen and B. Heldt, 'International peacekeeping: The UN versus Regional organisations,' in J. J. Hewitt, J. Wilkenfeld, and T. R. Gurr (eds.), Peace and conflict 20o8, Boulder, Paradigm Publishers, 2008, pp. 93-106. G. Wilson, 'UN authorized enforcement: regional organizations versus "coalitions of the willing," International peacekeeping, Vol. 10, No. 2, 2003, pp. 89-106. 4 On this point see F. Attinà, 'Global power competition and the rise of minilateralism' in F. Attinà and D. Irrera op.cit., pp. 19-34.
} 
democratic status and culture, economic wealth, large population and army, and Western or pro-Western international positions of government that sustain a propensity to participate in, and bear the costs of, peace operations. 5 The core sections of this paper focus on assessing the EU Member States' involvement in CSDP operations.

\section{CSDP operations: an overview}

Twenty-six EU peace operations are counted as of 30 September 2010. In 1991, the European Community monitoring mission (ECMM) was set up and dispatched to the Balkans. Later, this pre-ESDP mission was converted in the EUMM within the CSDP frame. In January 2003, the first civilian (police) mission, EUPM BiH, was deployed in Bosnia-Herzegovina. In the same year, two military missions were put on the ground in Macedonia-FYROM, the Concordia mission, and in the Democratic Republic of Congo, the Artemis mission. In December 2003, Concordia was replaced by the civilian mission Proxima, and this one by EUPAT in June 2005. Out of the twenty-six, seven are military, seventeen civilian, and two missions are mixed. The last ones - the EU support operation mission to AMIS II in Darfur and EUSEC in DRC - are charged with both military and civilian tasks. The civilian operations are assigned to collaborate with the local authorities to accomplish tasks like police and judicial reform, border training, and reform of the local army, according to human rights and democratic standards. At least fourteen operations have been active in each year from 2005 to 2010. In 2010, the number of active operations was eighteen (Figure 1). Four of them were military and one operation was mixed. Thus, for CSDP the main effort is in the civilian sector ${ }^{6}$

Figure 1: New, completed and active CSDP operations by year

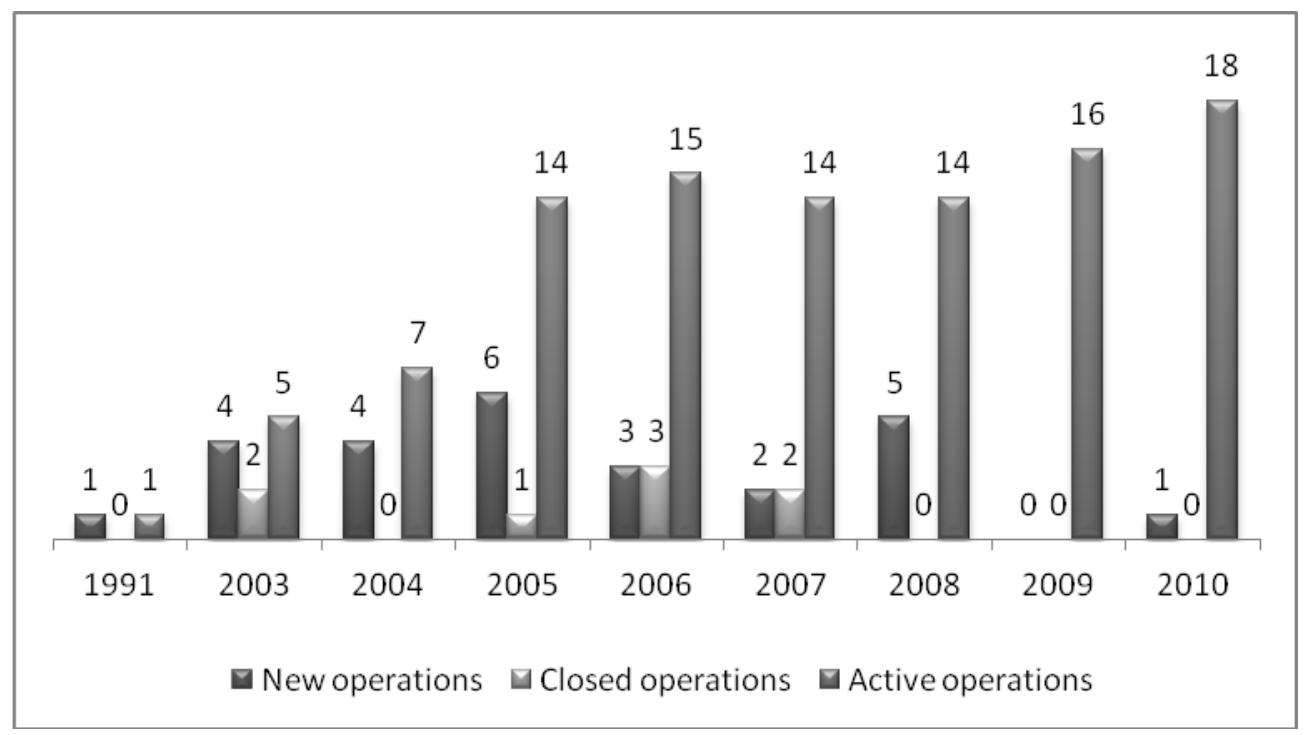

5 F. Attinà, 'European propensity to peacekeeping and minilateralism: a quantitative analysis of four EU countries and ESDP operations', op. cit, pp. 105-124.

${ }^{6}$ See the complete list of the missions and data here analyzed at the ADISM website

<http://www.fscpo.unict.it/adism/adism.htm>, accessed January 20,2011. 
Source: ADISM http://www.fscpo.unict.it/adism/adism.htm>, accessed 20 January, 2011.

The four completed civilian missions in Europe (Proxima-EUPAT in FYROM on police reform, and EUJUST Themis in Georgia on judicial reform), Africa (EUPOL Kinshasa on police reform), and South-East Asia (AMM in Aceh). The thirteen civilian missions active in 2010 took place in Europe, namely in the Balkans (EUMM and EUPM BiH in Bosnia, EUSR BST and EUMM in Georgia, EUPT and EULEX in Kosovo, and EUBAM in Moldova/Ukraine), in the Middle East (EUJUST Lex in Iraq, and EUBAM Rafah and EUPOL-COPPS in Palestine Territories), in Africa (EUPOL RD Congo and EUSSR Guinea-Bissau) and in Asia (EUPOL Afghanistan).

As far as the EU military missions are concerned, five were deployed in Africa, including the two short completed missions, Artemis and EUFOR, that were dispatched to RD Congo in accordance with the United Nations. The three EU military missions active in Africa in 2010 are the EUFOR mission in Chad and the EUNAVFOR/Atalanta and EUTM in Somalia. The remaining military missions are the completed Concordia mission in FYROM and the active EUFOR-Althea mission in Bosnia.

The military and civilian capabilities of crisis management, conflict resolution and state rebuilding have been created to serve the aspiration of the European Union to function as a global actor, i.e. as an actor capable of intervening in all the theatres of the world and of playing responsibly in all the major global institutions. However, at the present time the EU's peace building operations focus predominantly on Europe and Africa. The CSDP capabilities are employed firstly to curb crises and conflicts in the EU's own region, and secondly in Africa. This conclusion is supported by taking into account the number of operations, the peak number of personnel involved, and the total duration of the operations (See Figure 2, Column A, C and D).

Figure 2: CSDP operations

\begin{tabular}{|c|c|c|c|c|c|}
\hline & $\begin{array}{c}\text { (A) } \\
\text { Number of } \\
\text { operations }\end{array}$ & $\begin{array}{c}\text { No. of active } \\
\text { operations in } \\
2010\end{array}$ & $\begin{array}{c}\text { (C) } \\
\text { Total of } \\
\text { personnel: } \\
\text { peak } \\
\text { numbers }\end{array}$ & $\begin{array}{c}\text { (D) } \\
\text { Total time } \\
\text { length } \\
\text { (years) }\end{array}$ & $\begin{array}{c}\text { (E) } \\
\text { Mean } \\
\text { time- } \\
\text { length } \\
\text { (years) }\end{array}$ \\
\hline Europe & 11 & 8 & 11505 & 55,8 & 5,1 \\
\hline Africa & 10 & 6 & 9935 & 19,9 & 2,0 \\
\hline Middle East & 3 & 3 & 175 & 14,6 & 4,9 \\
\hline Asia & 2 & 1 & 544 & 4,5 & 2,3 \\
\hline & 26 & 18 & 22159 & 94,3 & 3,6 \\
\hline
\end{tabular}

Source: ADISM < http://www.fscpo.unict.it/adism/adism.htm>, accessed 20 January, 2011.

In the past seven years, armed conflicts have been more numerous in Asia than in Africa (Figure 3) but the European Union and the United Nations have been much more willing and able to engage in multilateral intervention in Africa than in Asia. In fact, from 2003-2008, 36 UN-led, Non-UN-led and ad hoc coalition operations were 
dispatched to Africa, eleven to Europe, nine to Asia, and six to the Middle East.7 Almost no attention has been given by the researchers and experts in peace operations to explain the difference in the recourse to multilateral intervention to curb violence and armed conflicts in Asia and Africa. Instead, a great deal has been written about the European Union as the main actor of peacekeeping and peace building in Europe. As argued elsewhere ${ }^{8}$, the high number of CSDP operations in Europe is consistent with the advanced stage of the European regional security partnership. This paper addresses the EU's minimal involvement in the peace missions dispatched to Asia in a later section.

Figure 3: Armed conflicts by region, 2003-2009

\begin{tabular}{|c|c|c|c|c|c|c|c|}
\hline Region & 2003 & 2004 & 2005 & 2006 & 2007 & 2008 & 2009 \\
\hline Asia & 16 & 14 & 16 & 15 & 14 & 15 & 15 \\
\hline Africa & 9 & 10 & 7 & 10 & 12 & 13 & 12 \\
\hline Middle East & 2 & 3 & 5 & 5 & 4 & 4 & 5 \\
\hline Europe & 1 & 2 & 2 & 1 & 2 & 2 & 1 \\
\hline
\end{tabular}

Source: Table II in L. Harbom \& P. Wallensteen, 'Armed Conflict, 1946-2009,' Journal of Peace Research, vol. 47, no. 4, 2010, pp. 501-509.

It is also worth drawing attention to the differences in the mean duration of the CSDP operations of the four areas (see Figure 2 column E) because this difference hints at an important feature of the EU's peace building action: the strong correlation between short duration and the mission's military mandate. In fact, seven of the ten heavily resourced and short in duration missions deployed in Africa are military missions. In Africa, then, the European Union has accomplished mainly the task of interrupting violence and has barely engaged in the ambitious task of peace building and state reconstruction. On the contrary, the peak number of CSDP missions for peace building by means of civilian personnel and know-how, , belongs to the group of missions deployed in Europe, which are also on average the longest in duration.

For the time being, then, the EU, as a global actor with a strong penchant for multilateralism, plays this capability in the backyard (the Balkans), the near-abroad (the Caucasus and the Middle East) and in the Sub-Saharan Africa, an area of knowledge and interest to Member States like France, United Kingdom and Belgium. The EU involvement in the Asian continent operations, instead, is small, although it is not lowprofile, as demonstrated by the Aceh Monitoring Mission and the EUPOL Afghanistan mission. The EU's minimal involvement in Asia can be explained by taking into account the following conditions. The societies and states of Asia are relatively unfamiliar to the Europeans; the deployment of missions is difficult and expensive due to the logistics, transportation and communication factors involved in this geographical distance; and

\footnotetext{
7 See the ADISM Dataset of 205 multilateral peace/security operations, 1947 - 2008 Codebook Version $2.2008<$ http://www.fscpo.unict.it/adism/adism.htm>, accessed 20 January, 2011.

8 F. Attinà, 'European propensity to peacekeeping and minilateralism: a quantitative analysis of four EU countries and ESDP operations', in op.cit..
} 
the conduct of operations is heavily conditioned by the interest and preference of those actors the EU is reluctant to oppose, such as China, India and the United States.

These remarks on the EU's uneven involvement in different continents are not meant to undermine the overall importance of the CDSP's contribution to the advancement of multilateral security and the hard work done by the EU and its Member States to enhance European peace building capabilities. These capabilities are outstanding in promoting the stability of the world system.

The next section of this paper examines the data of the Member States participation in CDSP operations to assess the EU states resolve on this task and in multilateral security. The relevant data highlights issues such as the EU Member States' propensity to assume the human and political costs of peace building operations, the allocation of mission control, where the prime positions have been restricted to a few Member States, and the engagement of the new Member States in the EU peace building policy, which in some cases started before their entry into the Union.

\section{EU Member States' participation in CDSP operations}

Generally speaking, participation in multilateral operations brings benefit to the national interests of the states involved and the collective interests of all the states. Examples of the kinds of collective and national interests which may underpin a country's rationale for participating in multilateral peace operations include creating stability in a geopolitical area of national concern, the enhancement of the state military and civilian capabilities, and improving a state's standing in the global political arena.. The defence of peace, security, law, and humanitarian principles in the world system is the overall collective interest the single state contributes to by participating in multilateral operations. Whatever the interest served by the participants, multilateralism is reinforced as international norm and practice by their action, and also becomes the constitutive part of their foreign policy culture. Still, states have different inclination towards taking on themselves the costs of supporting multilateral security and direct participation in peace operations. There are frequent, medium and low participants in as well as free-riders of multilateral security.

Research demonstrates that democracy makes states highly disposed to take part in peace operations 9 . The same is true for economic wealth. The analysis of the participation of France, Italy, Spain, and Sweden in the UN and Non-UN peace operations during the time of the current world system confirms the link between democracy and propensity to participate in multilateral operations of the states. Additionally, it demonstrated that factors like the size of the population, the level of the

\footnotetext{
9 A. Andersson, 'United Nations Intervention by United Democracies? State Commitment to UN Interventions 1991-99', Cooperation and Conflict, Vol. 37, No. 4, 2002, pp. 363-386. A. Andersson, 'Democracy and susceptibility to UN intervention', International peacekeeping, Vol. 13, No. 2, 2006, pp. 184-199. D..C.F Daniel and L. C. Caraher, 'Characteristics of troop contributors to peace operations and implications for global capacity', International peacekeeping, Vol. 13, No. 3, 2006, pp. 297-315. J. H. Lebovic, 'Uniting for Peace? Democracies and United Nations peace operations after the Cold War', Journal of Conflict Resolution, Vol. 48, No. 6, 2004, pp. 910-937.
} 
economic wealth, and the international position and foreign policy orientation have significant influence on the frequency of participation and the extent of the contribution to the operation resources and capabilities. ${ }^{10}$

The growth in number of peace operations in the last twenty-five years has been fuelled by the arrival of new participants in multilateral peacekeeping missions, alongside the traditional rich democracies. In fact, in recent years, the number of countries that are neither wealthy nor democratic contributing personnel to peace operations has been growing. This rise in the number of countries participating in multilateral peace operations is largely due to the Unpoliced of funding participation by paying a daily sum to the government of the participating states for providing personnel. Regarding the EU, instead, only the common expenditures of the CSDP military missions are funded by the EU through the Athena mechanism if the Council so decides. The EU and non-EU Member States in the CSDP operations hold the costs and expenditures of their participation in the other cases of operations.

Studying the participation of the EU Member States in the CSDP operations is also a way to signal the EU countries socialization to multilateralism. This occurs because the government and military of the participating countries experience the condition of working in a collective setting and are affected by the common practices of violence control. Although a number of the new EU Member States participated in UN and NATO peace operations, and some of them were involved in EU peace missions before their entry into the Union, being a member of the CSDP operation machine is an experience of its own. The EU, like all the international organisations that put in place peace operations, develops its own practice of organising peace operations in addition to specific rules of conduct during the operation activities. Consequently, the new participating countries have to cope with the existing ways of doing things, accept preordered priorities and conform to pre-established restrictions. This socialization and learning is necessary to form the EU common capabilities of crisis management, conflict resolution and state reconstruction.

The following brief analysis of the presence of the EU Member States in the CSDP operations renders an image of the peace mission actor-ship in the formative years of the CSDP. The data of the presence of the EU Member States, available for 19 out of 26 operations, rank the new Member States in the lowest echelons (Figure 4). The history of these countries in the last sixty years made them scarcely engaged in developing peace operation capabilities. The process of democracy-building after the fall of the socialist regime promoted the learning of the culture of multilateralism and the practice of peace operations. However, the low rank in the scale of the characteristics that are associated to frequent participation in peace operations, i.e. demographic size, military power and economic wealth (see Figure 4), accounts for the low presence of these countries in the CSDP operations. Denmark's special position on, and opt-out from, the CSDP is the cause of the Danish presence in the "low presence group" together with the new EU Member States. Hungary is the only new member country that has been given

${ }^{10} \mathrm{~F}$. Attinà, 'European propensity to peacekeeping and minilateralism: a quantitative analysis of four EU countries and ESDP operations,' in op.cit.. 
the task of guiding one CSDP mission of those recorded in the dataset (Figure 5). All the operations have a Head of Mission and, in the case of military and mixed missions, a Commander. Other chief positions also exist but of less importance. The turn-over of the people and country in charge of the head/commander position occurs regularly in the life of the missions but is rather biased towards the nationals of a small group of countries, namely France, Germany and UK (see Figure 5). These countries are the members of the "frequent participant" group as well as of the group of the large and rich countries of the Union. Possibly, they have considerable knowledge of the organisation of military and civilian missions. They have also skills and capabilities that stem from the past great power experience, and colonial ties to African states in the case of France and the UK. On the contrary, Italy, a large country, and Sweden, a rich one, are left out of the "head/commander group" in spite of belonging to the top of the "frequent participant" group.

Figure 4: EU member country presence in CSDP operations

\begin{tabular}{|c|c|c|c|c|c|c|}
\hline $\begin{array}{c}\text { (A) } \\
\text { Country } \\
\text { name }\end{array}$ & $\begin{array}{c}\text { (B) } \\
\text { Population } \\
\text { (millions) } \\
2007\end{array}$ & $\begin{array}{c}(\mathrm{C}) \\
\text { Military } \\
\text { expenditures } \\
\text { (million \$) } \\
2009\end{array}$ & $\begin{array}{c}\text { (D) } \\
\text { GDP } \\
\text { (million } \\
\text { Euro) } \\
2009\end{array}$ & $\begin{array}{c}\text { (E) } \\
\text { Presence } \\
\text { in } 11 \\
\text { civilian } \\
\text { missions }\end{array}$ & $\begin{array}{c}(\mathrm{F}) \\
\text { Presence } \\
\text { in the } 7 \\
\text { military } \\
\text { and } 1 \\
\text { mixed } \\
\text { missions }\end{array}$ & $\begin{array}{c}(\mathrm{G}) \\
\text { Total } \\
\text { presence } \\
\text { in } 19 \text { out } \\
\text { of } 26 \\
\text { CSDP } \\
\text { operations }\end{array}$ \\
\hline France & 63,4 & 67.316 & 29.600 & 10 & 8 & 18 \\
\hline Italy & 59,1 & 37.427 & 25.200 & 10 & 6 & 16 \\
\hline Sweden & 9,0 & 6.135 & 31.300 & 9 & 7 & 16 \\
\hline Germany & 82,3 & 48.022 & 29.300 & 9 & 6 & 15 \\
\hline Belgium & 10,6 & 5.674 & 31.400 & 7 & 7 & 14 \\
\hline Finland & 5,3 & 3.768 & 32.100 & 9 & 5 & 14 \\
\hline Portugal & 10,6 & 4.884 & 15.800 & 8 & 6 & 14 \\
\hline Spain & 44,5 & 19.409 & 22.900 & 8 & 6 & 14 \\
\hline $\begin{array}{c}\text { United } \\
\text { Kingdom }\end{array}$ & 60,9 & 69.271 & $25 \cdot 300$ & 7 & 7 & 14 \\
\hline Netherland & 16,3 & 12.642 & 34.600 & 8 & 5 & 13 \\
\hline Austria & 8,3 & 3.650 & 32.800 & 7 & 5 & 12 \\
\hline Hungary & 10,1 & 1.900, & 9.300 & 6 & 6 & 12 \\
\hline Greece & 11,2 & 13.917 & 20.700 & 5 & 6 & 11 \\
\hline Ireland & 4,3 & 1.581 & 35.700 & 6 & 4 & 10 \\
\hline Luxembourg & 0,5 & 406 & 76.500 & 4 & 6 & 10 \\
\hline Poland & 38,2 & 10.860 & 8.100 & 6 & 4 & 10 \\
\hline $\begin{array}{c}\text { Czech } \\
\text { Republic }\end{array}$ & 10,3 & 3.246 & 13.100 & 7 & 2 & 9 \\
\hline Slovakia & 5,4 & 1.316 & 11.700 & 5 & 4 & 9 \\
\hline Estonia & 1,2 & 460 & 10.300 & 6 & 2 & 8 \\
\hline Lithuania & 3,4 & 648 & 7.900 & 5 & 3 & 8 \\
\hline
\end{tabular}




\begin{tabular}{|c|c|c|c|c|c|c|}
\hline Romania & 21,6 & 2.616 & 5.400 & 6 & 2 & 8 \\
\hline Slovenia & 2,0 & 888 & 17.300 & 5 & 3 & 8 \\
\hline Denmark & 5,4 & 4.476 & 40.400 & 7 & 0 & 7 \\
\hline Latvia & 2,3 & 692 & 8.200 & 5 & 2 & 7 \\
\hline Cyprus & 0,8 & 550 & 21.200 & 4 & 2 & 6 \\
\hline Bulgaria & 7,7 & 1.127 & 4.700 & 3 & 2 & 5 \\
\hline Malta & 0,4 & 51 & 13.900 & 4 & 1 & 5 \\
\hline
\end{tabular}

Sources: Population and GDP: EUROSTAT. Military expenditures: SIPRI military expenditures database. Participation in CSDP operations: ADISM <http://www.fscpo.unict.it/adism/adism.htm >, accessed 20 January, 2011. The bold character in column (A) indicates the new Member States, in columns (B) (C) (D) the numbers above the mean value which, respectively, is $18,3,11.960$, and 22.766 .

Figure 5: EU member country presence and head/commander position in CSDP operations

\begin{tabular}{|c|c|c|c|c|c|}
\hline $\begin{array}{l}\text { (A) } \\
\text { Country } \\
\text { name }\end{array}$ & $\begin{array}{c}\text { (B) } \\
\text { Population } \\
\text { (millions) } \\
2007\end{array}$ & $\begin{array}{c}(\mathrm{C}) \\
\text { Military } \\
\text { expenditures } \\
\text { (million \$) } \\
2009\end{array}$ & $\begin{array}{c}\text { (D) } \\
\text { GDP } \\
\text { (million } \\
\text { Euro) } \\
2009\end{array}$ & $\begin{array}{l}\text { (E) } \\
\text { Presence } \\
\text { in CSDP } \\
\text { missions }\end{array}$ & $\begin{array}{c}(\mathrm{F}) \\
\text { Head/commander } \\
\text { position }\end{array}$ \\
\hline France & 63,4 & 67.316 & 29.600 & 18 & 9 \\
\hline Germany & 82,3 & 48.022 & 29.300 & 15 & 7 \\
\hline $\begin{array}{l}\text { United } \\
\text { Kingdom }\end{array}$ & 60,9 & 69.271 & $25 \cdot 300$ & 14 & 6 \\
\hline Spain & 44,5 & 19.409 & 22.900 & 14 & 4 \\
\hline Sweden & 9,0 & 6.135 & 31.300 & 16 & 4 \\
\hline Italy & 59,1 & 37.427 & 25.200 & 16 & 3 \\
\hline Portugal & 10,6 & 4.884 & 15.800 & 14 & 3 \\
\hline Denmark & 5,4 & 4.476 & 40.400 & 7 & 2 \\
\hline Ireland & 4,3 & 1.581 & 35.700 & 10 & 2 \\
\hline Netherland & 16,3 & 12.642 & 34.600 & 13 & 1 \\
\hline Belgium & 10,6 & 5.674 & 31.400 & 14 & 1 \\
\hline Austria & 8,3 & 3.650 & 32.800 & 12 & 1 \\
\hline Hungary & 10,1 & 1.900 & 9.300 & 12 & 1 \\
\hline
\end{tabular}

Data available on 25 missions. Source: ADISM < $\underline{\text { http://www.fscpo.unict.it/adism/adism.htm>, accessed }}$ 20 January, 2011. The bold text in column (A) indicates the new Member States, in columns (B) (C) (D) the numbers above the mean value, which, respectively, is 29,6, 21.722, and 27.966.

\section{Concluding remarks}

The European Union wishes to function as responsible actor in global politics. To this end, it has been particularly concerned with developing common civilian capabilities of conflict resolution and post-conflict reconstruction. The present analysis largely confirms that this objective is sustained by consequential decisions regarding multilateral security cooperation. In particular, this analysis has demonstrated that 
1. the European Union has deployed a large number of civilian missions in countries in need of assistance and that the common civilian capabilities have been employed mainly in the missions that have been dispatched to countries in Europe, the periphery of Europe, and Africa rather than in distant areas from Europe;

2. the economic costs of the missions are covered by the EU to a small extent as common expenditures and to a large extent by the Member States on the base of the country size and wealth. Consequently, mostly the old Member States have taken on themselves the largest amount of the costs and expenditures of the missions;

3. the new Member States have been fully admitted and socialized to CSDP operations, but the leading position of the EU peace missions has been for the most part the preserve of a small group of old Member States.

The increasing number of CSDP operations deployed in and out of Europe since 2003 demonstrates the increasing will and capability of the European Union to act as both regional (i.e. European) security organizer and as a global security player. Is Europe in tune with the current peace operation practice, that is with the state-building and reconstruction goals that it contributed to enhance as the main goals of multilateral security? To play effectively as the leading actor of civilian missions on the world stage, the European Union has to continue to update the existing military and civilian capabilities and meet with three main challenges.

The EU actorship in multilateral security depends on employing the appropriate instruments to carry out the controversial task of peace building. In fact, post-conflict reconstruction is censured by many state governments as being a tool chosen by mission organisers for exporting their own political and economic projects. The re-building of a state broken by civil war implies to some extent the restriction of its sovereignty, at least temporarily. Therefore, the European policy-makers have to take into serious consideration any discontent surrounding their approach to peace-building. In order to enhance the future development of the EU's capabilities of crisis and conflict management less intrusive ways of supporting peace and re-building stability in the countries of CSDP operations must be accurately prepared. Analysts point to the positive role that nongovernmental organizations play in the mission-receiving country and the consequent strengthening of the legitimacy and efficiency of the mission because NGOs are seriously committed to amplifying the local actors' expectations on social, political, and practical needs. ${ }^{11}$ In moving towards less intrusive methods of crisis management, the EU has to expand the participation of nongovernmental groups in CSDP missions.

The Security Sector Reform (SSR) has become one of the most important tasks in mission-receiving countries. It deals with police reform, judicial backing, border training and other similar actions. The EU, as one of the most proactive actors in the

11 D. Irrera, 'NGOs' roles in humanitarian interventions and peace support operations,', in Attinà and Irrera, op. cit., 2010, pp. 71-86. 
SSR area, must be aware of the need for mandating these tasks to well-trained experts. In particular, the reform of the defence sector and the transformation of police and the judiciary in the receiving states needs to take the need for the democratic control of these sectors into due consideration.

Lastly, it is worth remembering that the leaders and the public of the participating countries must be prepared to commit to huge mission because peace building missions must normally last for a long time to achieve the expected results. Therefore, the mission actors have to steadfastly uphold their commitment to see the whole operation through. This means that the EU and its Member States will have to overcome the obstacles and set-backs, such as 1 unexpected casualties and rising financial costs which influence domestic political competition and may hamper the resolve to complete a peace building operation. 